\title{
Isolation, identification, and antimicrobial susceptibility of Brucella spp. cultured from cows and goats manure in Mexico ${ }^{\#}$
}

\author{
Aislamiento, identificación y susceptibilidad antimicrobiana de Brucella spp. \\ cultivadas de materia fecal de vacas y cabras en México \\ AI Morales-Estrada ${ }^{a}$, R Hernández-Castro ${ }^{\mathrm{b}}$, A López-Merino ${ }^{\mathrm{a}}$, \\ J Singh-Bedic ${ }^{\mathrm{c}}$ A Contreras-Rodríguez ${ }^{\mathrm{a}^{*}}$
}

\begin{abstract}
Brucellosis is a zoonosis that affects many animal species worldwide. Humans are often infected through direct animal contact, through contact with animal excretions, or through ingestion of unpasteurized dairy products. Livestock manure is extensively used as a pasture fertilizer in many production systems, especially in non-developed countries. Some microbiological studies warn of the risk of manure being a disseminator vector of pathogenic microorganisms. The present study aimed to isolate Brucella in manure from cows and goats that were serologically positive for brucellosis in an endemic region of Mexico. We then used E-test methods to evaluate the isolated microorganisms' susceptibility to antimicrobial agents in vitro. Brucella isolation was performed via a pre-enriched selective culture, and subcultures using selective agar plates. Isolates were identified using microbiological tests as well as BCSP31 PCR and Bruce-Ladder multiplex PCR. We isolated 10 Brucella spp. strains, all of which amplified the genus-specific gene that encodes the BCSP31 protein. The species were identified using multiplex PCR. Interestingly, B. melitensis, B. abortus, and $B$. suis were isolated from cow manure, while $B$. abortus was just isolated from goat manure. The isolates did not include any strains that are routinely vaccinated against. Some isolates were resistant to ciprofloxacin, levofloxacin, trimethoprim-sulfamethoxazole, and rifampicin. Manure from infected animals could represent a vehicle for human exposure to Brucella. More detailed studies are needed to evaluate Brucella-contaminated manure as a risk factor in endemic regions.

Key words: brucellosis, Brucella, manure, zoonosis.
\end{abstract}

RESUMEN. La brucelosis es una zoonosis distribuida mundialmente que afecta varias especies animales. Los humanos se infectan por el contacto con animales infectados, sus excreciones o por la ingesta de derivados lácteos no pasteurizados. Las heces excretadas por el ganado se usan como fertilizante en países no desarrollados. Estudios microbiológicos han alertado sobre el riesgo de las heces o estiércol como vector de diseminación de microorganismos patógenos. El objetivo de este trabajo fue aislar Brucella de heces de vacas y cabras y evaluar la sensibilidad contra antimicrobianos mediante el método de E-test. Se analizaron heces de vacas y cabras serológicamente positivas a brucelosis de una región endémica de México. El aislamiento de Brucella se llevó a cabo en un medio de preenriquecimiento y posteriormente se aisló en medio selectivo. La identificación se realizó mediante pruebas microbiológicas y por PCR. Se obtuvieron 10 aislados de Brucella spp., que fueron positivos a la amplificación del gen específico de género que codifica para la proteína BCSP31 y mediante multiplex Bruce-Ladder se identificó la especie. Se demostró la presencia de B. melitensis, $B$. abortus y $B$. suis en las heces de las vacas, mientras que $B$. abortus solo se aisló de las cabras. Ninguna cepa vacunal se encontró en el estudio. Algunos aislados fueron resistentes a ciprofloxacina, levofloxacina, trimetoprim-sulfametoxazol, y rifampicina. Las heces de animales infectados representan un riesgo de exposición a Brucella. Se requieren estudios más detallados para evaluar el factor de riesgo asociado a la materia fecal contaminada con Brucella en regiones endémicas.

Palabras clave: brucelosis, Brucella, heces, zoonosis.

\section{INTRODUCTION}

Animal manure, a fecal waste generated by livestock, has a long tradition of use in agriculture as a valuable

Accepted: 10.12 .2015 .

aDepartamento de Microbiología, Escuela Nacional de Ciencias Biológicas, Instituto Politécnico Nacional, México, D.F.

birección de Investigación, Departamento de Ecología de Agentes Patógenos, Hospital General Dr. Manuel Gea González, Tlalpan, México.

'School of Public Health \& Zoonoses, Guru Angad Dev Veterinary and Animal Sciences University, Punjab, India.

\#Funded by CONACYT CB-2011-01 No. 169259, SIP-IPN 20144471 and ICYT-DF/IPN

Corresponding author: A Contreras-Rodríguez, Prol. Carpio y Plan de Ayala s/n, Col. Sto. Tomás, CP 11340, Mexico, D.F; aracelicontreras21@ gmail.com source of available plant nutrients and organic matter, improving soil quality and fertility. However, the manure of wild and domestic animals can contain a wide variety of pathogenic viruses, bacteria, and parasites, and thus manure use carries a risk of spreading animal diseases and zoonotic agents. Several studies have investigated the prevalence and levels of pathogenic bacteria in manure, including Salmonella, Campylobacter, Escherichia coli O157:H7, and Listeria (Hutchison et al 2005). Brucella can survive in manure experimentally, but little is known about the risk for humans in contact with naturally infected manure in the field. Wallach et al (2008) reported an outbreak of human brucellosis among farm workers in Mendoza, Argentina, which was attributed to contact with manure of infected goats. In this outbreak, Brucella melitensis was isolated from milk of goats and in blood cultures from farm workers. 
Brucellosis is caused by multiple species of the Brucella genus. B. melitensis is the most pathogenic species, followed by B. abortus and B. suis. These bacteria can infect a wide variety of animals, including cattle, pigs, sheep, goats, horses, and dogs. Brucella can be excreted in vaginal fluids, including with aborted fetuses, and thus may contaminate feces and bedding (Corbel 1997). Brucella can be transmitted from infected animals to humans through direct contact with aborted fetuses and related materials, as well as through consumption of raw milk or unpasteurized dairy products (Corbel 1997). This study reports Brucella isolation and identification from the manure of cows and goats that were serologically positive for brucellosis. It also evaluated the antimicrobial susceptibility of these Brucella isolates.

\section{MATERIAL AND METHODS}

\section{ANIMAL SAMPLES}

The investigated animals were from 3 farms located in a brucellosis endemic region of Mexico. We serologically analyzed 5 dairy herds with approximately 60 cows, and 3 herds with 50 goats. Sampling was performed during August and September of 2012. Animal blood was taken from the jugular vein for use in serological tests. Cow serum was analysed using the card agglutination test, and positive results were confirmed by rivanol tests (agglutination titers $\geq 1: 50$ were considered positive for brucellosis) (Norma Oficial Mexicana NOM-041). Goat serum was also analysed using the card agglutination test, and positive results were confirmed by complement fixation test (titers $\geq 1: 8$ were considered positive for brucellosis) (Norma Oficial Mexicana NOM-041). Testing revealed that 20 cows and 10 goats were serologically positive for brucellosis, corresponding to around $60 \%$ of the population of these farms. Manure samples were collected in sterilised plastic bottles directly from the anus of each animal, and were transported to the laboratory at $4{ }^{\circ} \mathrm{C}$. Samples were analysed in the laboratory within $24 \mathrm{~h}$ after collection.

\section{BRUCELLA ISOLATION AND IDENTIFICATION}

The pre-enriched broth medium was prepared with tryptic soy broth (Becton Dickinson); $0.5 \%$ yeast extract; $5 \%$ horse serum; $1 \%$ glucose; and commercially available Brucella selective supplement (Oxoid catalog number SR0209E), which contains polymyxin B, bacitracin, natamycin, nalidixic acid, nystatin, and vancomycin and was prepared according to the manufacturer's recommendations. For agar plates, the formulation was the same with addition of $2 \%$ agar.

We added $15 \mathrm{~g}$ of each manure sample to bottles with $200 \mathrm{~mL}$ of pre-enriched broth medium, and these bottles were incubated at $37^{\circ} \mathrm{C}$ for $48 \mathrm{~h}$ in a shaking incubator.
The contents of each bottle were then filtered by syringe with a sterile cotton ball to remove solid debris, and the liquid was centrifuged at $3,000 \times g$ for $30 \mathrm{~min}$. After centrifugation, $0.5 \mathrm{~mL}$ of the resulting pellet was spread on selective agar plates containing antibiotics, which were incubated at $37^{\circ} \mathrm{C}$ with $5 \% \mathrm{CO}_{2}$ for 5 to 15 days. Colonies showing a Brucella phenotype were selected and microbiologically typed based on $\mathrm{H}_{2} \mathrm{~S}$ and urease production, fuchsin and thionin sensitivity, lysis by Brucella-specific bacteriophages (Tbilisi, Weybridge and Berkeley), and agglutination with monospecific $\mathrm{A}$ and $\mathrm{M}$ antisera (Alton et al 1988).

To estimate the number of Brucella in each manure sample, the pellet obtained by centrifugation (as described above), was dissolved in $0.5 \mathrm{~mL}$ sterile saline. We then performed a ten-fold serial dilution in sterile saline. Aliquots of $0.5 \mathrm{~mL}$ were inoculated on selective antibiotic-containing agar plates, and the colonies on the plates were counted to obtain the CFU of Brucella/g.

\section{MOLECULAR IDENTIFICATION OF BRUCELLA ISOLATES}

Genomic DNA was obtained using the previously described cetyltrimethylammonium bromide (CTAB) method (Wilson 1987). All isolates were tested by amplification of the bcsp 31 genus-specific gene, and multiplex Bruce-Ladder PCR to identify Brucella species as reported previously (Morales-Estrada et al 2012). The reference strains B. melitensis $16 \mathrm{M}, B$. abortus 2308 , and B. suis 1330 were used as positive controls, and Ochrobactrum anthropi was used as a negative control.

Antimicrobial susceptibility testing

We used the E-test method (Biomerieux, Sweden) to determine the minimal inhibitory concentration (MIC) values of tetracycline, rifampicin, ciprofloxacin, levofloxacin, and trimethoprim-sulfamethoxazole (TMP-SMX). Briefly, for each Brucella strain, we created a bacterial suspension adjusted to a turbidity equivalent of $0.5 \mathrm{McF}$ arland standard. These bacterial suspensions were spread onto Mueller-Hinton (Oxoid catalog number CM337) agar plates supplemented with 5\% sheep's blood, and one E-test strip was placed on the plate. The plates were incubated at $37^{\circ} \mathrm{C}$ for $48 \mathrm{~h}$. The MIC was considered the value at which the inhibition zone intercepted the scale on the E-test strip. B. abortus 2308, B. melitensis $16 \mathrm{M}$, and B. suis 1330 were used as positive controls, and Escherichia coli ATCC 25922 and Staphylococcus aureus ATCC 29213 were used as quality control strains for susceptibility testing (Hashim et al 2014). The MIC values of tetracycline, ciprofloxacin, and TMPSMX for Brucella spp. were interpreted as recommended by the Clinical and Laboratory Standards Institute (CLSI). For rifampicin and levofloxacin, we used the Haemophilus spp. breakpoint recommended for slow-growing bacteria because no breakpoints were defined for Brucella. Based on these criteria, the tested strains were classified as resistant or sensitive to these antimicrobials. 


\section{RESULTS AND DISCUSSION}

Dilution plating revealed 2-100 CFU of Brucella/g from each sample. Based on monospecific antisera, bacteriophages, and microbiological results, we identified three isolates from cow manure as $B$. abortus biovar 1, three isolates from cow manure as $B$. melitensis biovar 1 , three isolates from goat manure as $B$. abortus biovar 1 , and one isolate from cow manure as $B$. suis biovar 1 .

Brucella species are generally host-specific but cross-species infections commonly occur when different species of animals share the same stables, pasture, or facilities. Cases of B. melitensis cross-infection have been described in mixed herds of sheep and goats in southern Europe (Verger et al 1989) and are regularly reported in the Middle East (Samaha et al 2008). Our present results show cross-infections with $B$. abortus, B. melitensis, and $B$. suis in a brucellosis endemic region of Mexico. Within this region, the main farm animals are cattle, followed by goats, sheep, and pigs. Herds of these animals co-exist closely, which likely contributes to the difficulty of eradicating brucellosis in this area.

Usually, brucellosis in cattle and goats is diagnosed based on serological studies, and it is not routine practice to isolate Brucella from animals in endemic regions of Mexico. Thus, little information is available regarding the prevalence of Brucella species in herds and flocks. Vaccines against brucellosis, B. abortus RB51 and B19, and $B$. melitensis Rev. 1, are administered to bovines and goats, respectively, in this region. Our present study included the use of the Bruce-Ladder, a multiplex PCR that can differentiate Brucella species and vaccine strains: B. abortus S19 and RB51 and B. melitensis Rev 1 (Morales-Estada et al 2012). Results of Bruce-Ladder PCR showed no vaccine strains among the Brucella isolates from manure (figure 1).

Brucella spp. are fastidious and relatively slow-growing microorganisms. Thus, their isolation from organs, tissue, or fluids of infected animals requires the use of selective media to reduce or eliminate the associated microbiota. Based on our experience and the reports of other authors, Brucella recovery in milk from $B$. abortus-infected cows ranges from 10 to 30\% (Langoni et al 2000). Our present results showed approximately 33\% recovery of Brucella spp. from the manure of serologically positive cows and goats using a pre-enriched selective medium.

The use of animal manure contaminated with zoonotic pathogens may promote the transfer of these pathogens. Our present finding of Brucella species in manure from domestic animals suggests a means of Brucella dissemination, and may represent a potential risk for animal and human health. Moreover, Brucella species can reportedly persist for several days or weeks in various environmental conditions depending on temperature and presence of organic materials. Data show that B. melitensis can survive in moist faeces for less than 75 days, while $B$. suis can survive for 120 days in cattle feces at room temperature, and for 4-37 days in soil (Burton and Turner 2003). Another report indicates that $B$. abortus can survive for 250 days in manure at $12{ }^{\circ} \mathrm{C}$ (Hagan et al 1988). In wolves experimentally infected with $B$. abortus biovar

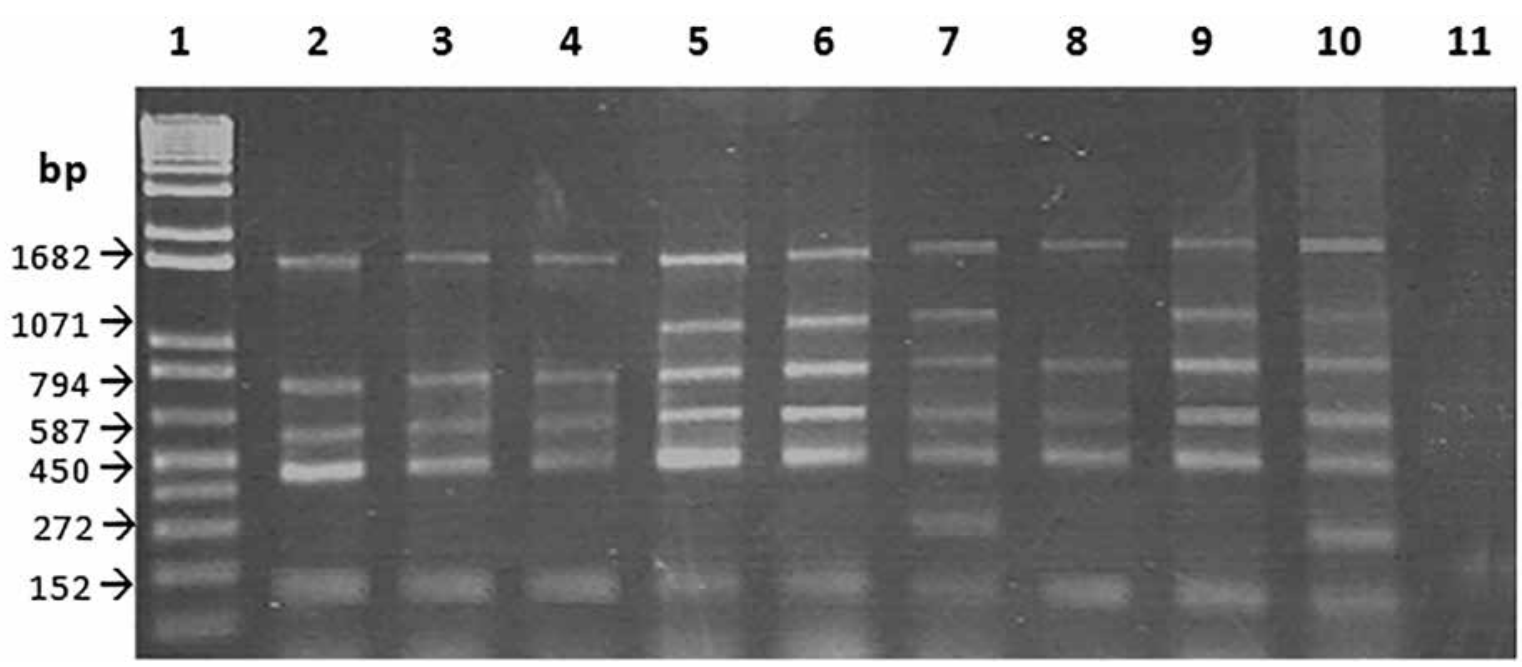

Figure 1. Multiplex PCR assay for the identification of Brucella strains isolated from samples of cow and goat faeces. Lane 1, 1-kb ladder; Lanes 2-4, B. abortus strains from goats; Lanes 5 and 6, B. melitensis strains from cows; Lane 7, B. suis strain from cow; Lanes 8, 9, and 10, positive control DNA from B. abortus 2308, B. melitensis 16M, and B. suis 1330, respectively; Lane 11, negative control DNA from Ochrobactrum anthropi.

Ensayo de PCR multiplex para la identificación de cepas de Brucella aisladas de la materia fecal de vacas y cabras. Pozo 1, Marcador de peso molecular $1 \mathrm{~Kb}$; pozo 2-4, cepas de B. abortus aisladas de cabras; pozos 5 y 6 , cepas de B. melitensis aisladas de vaca; pozo 7, cepa de $B$. suis aislada de vaca; pozos 8-10, testigo positivo (DNA de B. abortus 2308, B. melitensis 16M y B. suis 1330, respectivamente); pozo 11, testigo negativo (DNA de Ochrobactrum anthropi). 
1, bacteria were cultured from manure for up to 50 days post-infection (Tessaro and Forbes 2004). One report describes a case of $B$. melitensis isolated from an abscess of the left foot in 3-year-old child who lived on a ranch and was in contact with cattle. The girl suffered a trauma from an unidentified object that caused the foot lesion, and it likely became contaminated with manure or other animal material present in the soil (Resendiz-Sanchez et al 2009). Recently, Jahne and coworkers (2015) reported that bioaerosol emitted from manure application sites following manure application may present significant public health risks to downwind receptors. The Center for Diseases Control and Prevention (CDC) states that Brucella has a low infectious dose and shows ease of aerosolization; however, the health risk of Brucella-containing manure bioaerosols has not been documented.

Brucella is an intracellular facultative bacterium that can potentially evade the immune system and produce a relapsing or chronic disease presenting with a broad spectrum of clinical manifestation and complications (Corbel 1997). Thus, the treatment for brucellosis in humans is long and based on the use of two antibiotics. Farm animals receive antibiotics during breeding and Brucella is transmitted from animals to humans; therefore, it was important to determine the sensitivity of Brucella isolates to antibiotics. For this purpose, we used the E-test method, an antibiotic susceptibility test that determines the MIC and that is recommended for fastidious and slow-growing microorganisms. The E-test uses strips that contain an antibiotic concentration gradient, enabling simple MIC determination. Based on breakpoints outlined by the CLSI in 2013 and 2014, we found that one B. abortus isolated from goats was resistant to rifampicin and TMP-SMX, and showed a MIC of $6 \mu \mathrm{g} / \mathrm{mL}$ for tetracycline. One $B$. melitensis isolate from cow manure was resistant to ciprofloxacin, levofloxacin, and TMP-SMX, and showed a MIC of $32 \mu \mathrm{g} / \mathrm{mL}$ for tetracycline. Finally, a B. suis isolate from cow manure was resistant to ciprofloxacin.
The rest of the isolates were sensitive to all antimicrobial agents (table 1).

Hashim et al (2014) recently reported the isolation of rifampicin-resistant $B$. melitensis from human patients. A previous study also tested Brucella isolates from Mexico against different antimicrobial agents, and found that all isolates (97 strains) were sensitive to quinolones, tetracycline, doxycycline, TMP-SMX, and rifampicin, but 6 strains of $B$. abortus were resistant to streptomycin (Lopez-Merino et al 2004). The results in this study showed that 3 isolated Brucella strains were resistant to quinolones. Furthermore, 2 isolated strains showed a high MIC for tetracycline (above $6 \mu \mathrm{g} / \mathrm{mL}$ ), which is one of the best options for brucellosis treatment. Unfortunately, we did not test streptomycin in the present work. The E-test method had previously been used by Maves et al (2011) with Brucella strains from Peru, and by Kasymbekov et al (2013) to investigate Brucella strains from Kyrgyzstan. Both of these prior reports showed that all isolates were sensitive to the tested antimicrobials. Due to the potential existence of resistant isolates, evaluating the sensitivity of Brucella strains to the antimicrobials used in therapy should be established as a routine method in clinical laboratories.

In summary, our present results showed the presence of different Brucella species in manure from cows and goats in an endemic brucellosis region. Some of the isolates were resistant to quinolones, TMP-SMX, and rifampicin. Manure from infected animals could be a vehicle for Brucella dissemination; therefore, we recommend careful management of this material. Further studies are needed concerning the environmental impact of Brucella-contaminated manure in endemic regions.

\section{ACKNOWLEDGEMENTS}

AIME was supported by CONACYT and PIFI-IPN scholarships. ACR and ALM were supported by fellowships from COFAA-IPN, SIPEDI, and SNI-CONACYT. RHC was supported by SNI-CONACYT. We thank Karellen García-Méndez for technical support.

Table 1. Antibiotic susceptibility of Brucella strains isolated from manure.

Susceptibilidad antimicrobiana de cepas de Brucella aisladas de materia fecal.

\begin{tabular}{|c|c|c|c|c|c|c|c|c|c|}
\hline \multirow{3}{*}{ Antibiotics } & \multicolumn{4}{|c|}{ B. abortus (6) } & \multirow{2}{*}{\multicolumn{2}{|c|}{$\frac{\text { B. melitensis (3) }}{\text { cow }}$}} & \multirow{2}{*}{\multicolumn{2}{|c|}{$\frac{\text { B. suis (1) }}{\text { cow }}$}} & \multirow{3}{*}{$\begin{array}{l}\text { Breakpoint for } \\
\text { susceptibility } \\
\quad(\mu \mathrm{g} / \mathrm{mL})\end{array}$} \\
\hline & \multicolumn{2}{|c|}{ goat } & \multicolumn{2}{|c|}{ cow } & & & & & \\
\hline & $(\mathrm{S})$ & (R) & $(\mathrm{S})$ & (R) & $(\mathrm{S})$ & (R) & $(\mathrm{S})$ & (R) & \\
\hline Tetracycline & 2 & 1 & 3 & 0 & 2 & 1 & 1 & 0 & $\leq 1^{\mathrm{a}}$ \\
\hline $\begin{array}{l}\text { Trimethoprim/ } \\
\text { Sulfamethoxazole }\end{array}$ & 2 & 1 & 3 & 0 & 2 & 1 & 1 & 0 & $\leq 2 / 38^{a}$ \\
\hline Ciprofloxacin & 3 & 0 & 3 & 0 & 2 & 1 & 0 & 1 & $\leq 1^{\mathrm{a}}$ \\
\hline Levofloxacin & 3 & 0 & 3 & 0 & 2 & 1 & 1 & 0 & $\leq 2^{\mathrm{b}}$ \\
\hline Rifampicin & 2 & 1 & 3 & 0 & 3 & 0 & 1 & 0 & $\leq 1^{b}$ \\
\hline
\end{tabular}

Standard breakpoints for Brucella spp. from Clinical and Laboratory Standards Institute guidelines.

Standard breakpoints for slowly growing bacteria (Haemophilus spp.) from Clinical and Laboratory Standards Institute guidelines. 


\section{REFERENCES}

Alton GG, LM Jones, RD Angus, JM Verger. 1988. Bacteriological methods. In: Techniques for the brucellosis laboratory. Institute National de la Recherche Agronomique, INRA, Paris France, Pp 34-60.

Burton CH, C Turner. 2003. Health risk from pathogens in livestock manures. In: Burton $\mathrm{CH}, \mathrm{C}$ Turner (eds). Manure management: treatment strategies for sustainable agriculture. $2^{\text {nd }} \mathrm{ed}$. Quae, UK, Pp 124-125.

CLSI, Clinical and Laboratory Standards Institute. 2013. M45-A2: Method for antimicrobial dilution and disk susceptibility testing of infrequently isolated or fastidious bacteria. $2^{\text {nd }} e d$. CLSI, Wayne, USA.

CLSI, Clinical and Laboratory Standards Institute. 2014. M100/S24: Performance standards for antimicrobial susceptibility testing; twenty-fourth information supplement, clinical and laboratory standards Institute. CLSI, Wayne, USA.

Corbel MJ. 1997. Brucellosis: an overview. Emerg Infect Dis 3, 213-221.

Hagan WA, DW Bruner, JF Timoney. 1988. $8^{\text {th }}$ ed. The genus Brucella. In: Hagan WA, DW Bruner, JF Timoney (eds). Hagan and Bruner's microbiology and infectious diseases of domestic animals. $8^{\text {th }} \mathrm{ed}$. Cornell University Press, UK, Pp 135-152.

Hashim R, N Ahmand, J Mohamed Zahidi, BY Tay, A Mohd Noor, S Zainal, H Hamzah, SH Hamzah, TS Chow, PS Wong, KN Leong. 2014. Identification and in vitro antimicrobial susceptibility of Brucella species isolated from human brucellosis. Int J Microbiol 2014, 596245.

Hutchison ML, LD Walters, SM Avery, F Munro, A Moore. 2005. Analyses of livestock production, waste storage, and pathogen levels and prevalences in farm manures. Appl Environ Microbiol 7, 1231-1236.

Jahne MA, S Roger, TM Holsen, SJ Grimberg, I Ramler. 2015. Emission and dispersion of bioaerosols from dairy manure application sites: Human health risk assessment. Environ Sci Technol 49, 9842-9849.

Kasymbekov J, J Imanseitov, M Ballif, N Schürch, S Paniga, P Pilo, M Tonolla, C Benagli, K Akylbekova, Z Jumakanova, E Schelling, J Zinsstag. 2013. Molecular epidemiology and antibiotic susceptibility of livestock Brucella melitensis isolates from Naryn Oblast, Kyrgyzstan. PLoS Negl Trop Dis 7, e2047.
Langoni H, SM Ichihara, AV Silva, RB Pardo, FB Tonin, LJP Mendoca, JAD Machado. 2000. Isolation of Brucella spp. from milk of brucellosis positive cows in São Paulo and Minas Gerais states. Braz J Vet Res Anim Sci 37, 305-307.

López-Merino A, A Contreras-Rodríguez, R Migranas-Ortiz, R OrrantiaGradín, GM Hernández-Oliva, AT Gutiérrez-Rubio, O Cardeñosa. 2004. Susceptibility of Mexican Brucella isolates to moxifloxacin, ciprofloxacin and other antimicrobials used in the treatment of human brucellosis. Scand J Infect Dis 36, 636-638.

Maves RC, R Castillo, A Guillen, B Espinosa, R Meza, N Espinoza, G Núñez, L Sánchez, J Chacaltana, D Cepeda, S González, ER Hall. 2011. Antimicrobial susceptibility of Brucella melitensis isolates in Peru. Antimicrob Agents Chemother 55, 1279-1281.

Morales-Estrada AI, J Castillo-Salto, A López-Merino, MR Morales-García, JG Valle-Valdez, A Contreras-Rodríguez. 2012. Characterization of Brucella species in Mexico by Bruce-Ladder polymerase chain reaction (PCR). Afr J Microbiol Res 6, 2793-2796.

Norma Oficial Mexicana NOM-041. 1995. Institute of Animal Health SAGARPA. Campaña nacional contra la brucelosis en los animales. Diario Oficial de la Federación, México.

Resendiz-Sánchez J, A Contreras-Rodríguez, A López-Merino, L Bravo-Guzmán, JG Valle-Valdez. 2009. Isolation of Brucella melitensis from an abscess on the left foot of a 3-year-old infant. J Med Microbiol 58, 267-269.

Samaha H, M Al-Rowaily, RM Khoudair, HM Ashour. 2008. Multicenter study of brucellosis in Egypt. Emerg Infect Dis 14, 1916-1918.

Tessaro SV, LB Forbes. 2004. Experimental Brucella abortus infection in wolves. $J$ Wildl Dis 40, 60-65.

Verger JM, B Garin Bastuji, M Grayon, AM Mahe. 1989. Brucella melitensis infection in cattle in France. Ann Rech Vet 20, 93-102.

Wallach JC, MC Ferrero, MV Delpino, CA Fossati, PC Baldi. 2008. Occupational infection due to Brucella abortus S19 among workers involved in vaccine production in Argentina. Clin Microbiol Infect $14,805-807$.

Wilson K. 1987. Preparation of genomic DNA from bacteria. In: Ausbel FM, Brent R, Kingston RE, Moore DD, Seidman JG, Smith JA (eds). Current Protocols in Molecular Biology. Wiley, New York, USA, Pp 2.4.1-2.4.5. 
